\title{
Digital Storytelling: An Attractive Media to Teach Narrative Text in Speaking Class
}

\author{
Muhammad Mujtaba Mitra Zuana \\ Institut Pesantren KH. Abdul Chalim \\ (mujtaba.mitrazuana@gmail.com)
}

\section{Key Words:}

Students' digital storytelling works

An attractive media

Narrative text

\section{Kata Kunci:}

Karya digital

storytelling siswa

Media yang menarik

Teks narasi

\section{ABSTRACT}

In 21st century, a huge change happens in which students prefer to learn by using digital technology. Some interesting digital technology devices are expected to apply by the teachers in the process of teaching and learning. One of the technologies that can be used in teaching activities is digital storytelling. The teachers can combine both personal narratives and the use of technology in their English classes. Thus, this study was conducted to describe the implementation of digital storytelling, the students' responses to the use of digital, and the students' digital storytelling works after implementing the media in the teaching and learning process. The design of this research was a descriptive qualitative. The researcher used Field notes, students' digital storytelling, and interview as instruments of collecting data. The researcher used data condensation, data display, and drawing conclusion to analyze the data. From Some findings of this study, the media can be considered as very attractive. They are eager to speak English during the process of video production. The media has significant role to decrease the students' anxiety in speaking. It has empowered them to make the digital storytelling video either inside or outside the classroom. At last, the students' ability is varied. The speaking criteria from O'Malley and Pierce's scoring rubric is not reached by all students.

\section{ABSTRAK}

Pada abad 21, perubahan besar terjadi di mana siswa lebih suka belajar dengan menggunakan teknologi digital. Beberapa perangkat teknologi digital yang menarik diharapkan dapat diterapkan oleh para guru dalam proses belajar mengajar. Salah satu teknologi yang dapat digunakan dalam kegiatan mengajar adalah digital storytelling. Para guru dapat menggabungkan narasi pribadi dan penggunaan teknologi dalam kelas bahasa Inggris mereka. Dengan demikian, penelitian ini dilakukan untuk menggambarkan penerapan digital storytelling, tanggapan siswa terhadap penggunaan digital, dan karya digital storytelling siswa berupa video setelah menerapkan media dalam proses belajar mengajar. Dari beberapa temuan penelitian ini, media dapat dianggap sangat menarik. Siswa memiliki keinginan tinggi berbicara bahasa Inggris selama proses produksi video. Media ini memiliki peran penting untuk mengurangi kecemasan siswa dalam berbicara. Mereka bisa mendapatkan kesempatan untuk membuat video digital storytelling baik di dalam maupun di luar kelas. Kriteria berbicara dari rubrik penilaian O'Malley dan Pierce tidak tercapai oleh semua siswa sehingga bisa dikatakan kemampuan mereka bervariasi.
Muhammad Mujtaba Mitra Zuana

Digital Storytelling: An Attractive Media to

Teach Narrative Text in Speaking Class
ALSUNA Vol. 1 (1), 2018 


\section{Introduction}

English language teacher should be able to play their role as a facilitator for students in their attempt to acquire the spoken language. The teacher should facilitate students in learning the spoken language by giving many oral practices. It is becoming a challenging task for language teachers to establish a successful language classroom. Foreign language classes have to incorporate playful dimension, thus the possibility for making the class as an instance of learning and a moment of fun becomes a key element of success in a language class (Kathleen and Nunan).

There many ways to make a fun activity in conversation class such as, using pictures, card, and other visual aids. A language teacher uses them as meaningful teaching aids in order to attract student's attention and facilitate them to understand the lesson better. Teacher expects to have right teaching techniques to provide students with appropriate teaching material and create a positive classroom environment (Harmer). Therefore, the students will have opportunity to practice English among themselves by using those kinds of medias.

Medias are considered as tools that can give contribution to the teaching and learning process. They can attract students' interest, bring positive attitude and make the teaching learning run well. We live in the world of technology so we, as the teachers of English language can ask ourselves, how to interconnect students' digital knowledge with storytelling because technology offers a number of opportunities for connecting classrooms with the world (Bull and Kajder).

In the 21st century, there has been such a huge change, in which the digital era appears so that students are already very familiar with the newest digital technology devices. They are able to use digital technology such as computers, digital cameras, cellphones, smartphones, internet, multimedia player (iPod), play station games and other digital technologies easily. Furthermore, there are a number of them actively involved in digital community such as blogs, facebook, twitter, path, bbm, whatsapp and even a video as an expression and creativity media like youtube. The development of information and communication technology offers convenience and a strong attraction to make the students prefer to interact with these technologies to people around them. 
Digital storytelling is one of the technologies that can be used in teaching activities. It is a useful mean how to combine both personal narratives with the use of technology in the classes of English language. Skouge and Rao (2009) define digital stories as multimedia projects employing the use of photographs, video, audio, and music. The digital storytelling process helps to transform isolated facts into illuminated, enduring understandings. By 'living in the story', we make the information come emotionally alive. By exploring 'lessons learned', we go beyond telling about content to find its deeper meaning (Porter). In short, digital stories combine the art of telling stories with a variety of digital multimedia such as images, audio, and video.

In teaching narrative text, digital storytelling helps teacher gain students' interest and involves them in the learning process because of its moving and interesting animations. It also contains subtitle of the story which can make the students understand about the story itself. The students' interest will make them feel comfortable in joining the learning process.

In addition, digital storytelling can help teacher in creating a creative media in order that the students will have high enthusiasm in teaching and learning process (Ohler). This media also can help students for improving their speaking skills. By using this media, the students are forced to be more creative in expressing their ideas through speaking. It can be an alternative media for teaching spoken narrative text and can be a trigger for the students eager to speak English especially telling a story.

There are several previous studies related to teaching speaking of narrative through digital storytelling. The first one is a study conducted by Afrilyasanti and Basthomi (2011). The research concluded that the activities involved in digital storytelling production potentially encourage students to actively speak up, improve their vocabulary, and train their pronunciation and fluency. In short, digital storytelling allows the student to communicate well using a foreign language they are learning. It should be noted that this present case study was carried out as an extracurricular activity. Relevant to this situation, we also need to note that the production of digital storytelling does not consume much time.

The second previous study was the thesis by Firza (2013) showing that the implementation of digital storytelling as student project in writing recount text to the second graders of junior high school was conducted properly according to the stages 
suggested by Suleiman (2011) as her theory. In case of students' writing, the students had understood the main concept of recount text. Thus, it can be concluded that digital storytelling can be applied to teach writing recount text.

As can be seen, the previous studies above aim to encourage the students more active and to enhance students' speaking and writing skill. However, none of the previous studies has focus on students' digital storytelling works. The process of making digital story telling gets more focus in this study in order to know the students' progress in speaking ability. Teaching and learning which has more focus on process is better than only on result (Brown).

Based on the background, the research questions of the study can be stated as follows:

1. How does the teacher apply digital storytelling in teaching narrative text in speaking class?

2. How do the students respond to the use of digital storytelling in speaking class?

3. How are the students' digital storytelling works after implementing digital storytelling in teaching and learning narrative text?

\section{Method}

In conducting this study, a descriptive qualitative research design was used. Descriptive qualitative studies describe phenomena and interpret what exists. It describes the situation that happening in the process of teaching and learning speaking narrative text in the classroom using digital storytelling.

According to Ary et al. (2010), qualitative research is designed to obtain information concerning about human behavior. How a researcher makes sense of interpreting human experiences at the time of the study becomes the focus. It aims to describe a natural situation without giving manipulation or special treatment to the subject of the study. In qualitative research, the researcher concerns with understanding and meaning through verbal narratives and observations rather than through numbers (McMillan).

In this study, the writer did not take part when the teaching and learning process was being done. He just observed the teaching and learning process in the class, described, and reported everything happening during the class. He evaluated and formulated the students' 
responses and the teacher's role when digital storytelling was applied after several meetings. In addition, the students' digital story telling works were evaluated to know the ability of the students in speaking. At the end of the study, the implementation of digital storytelling as media in learning spoken narrative text could be implemented in the teaching speaking of senior high school students well.

The subject of the study was English teacher and the students of a senior high school in Mojokerto. The researcher chose them as subject of the study because they had applied digital storytelling as a media in teaching and learning process of spoken narrative text. It was needed because this research requires participants who are familiar with the concept of digital storytelling and narrative text.

The data were about the implementation of digital storytelling as an alternative media in teaching and learning narrative text orally. The data themselves were expected to enable the researcher to get the information about whole aspect of the implementation of digital storytelling as an alternative media in learning narrative text orally, students' responses to the use of digital storytelling as an alternative media in learning narrative text orally, and the students' spoken narrative works after the implementation of digital storytelling. Observation, documentation, and interview were used by the researcher to collect the data.

To analyze data, the research followed the concept of Milles, Huberman, and Saldana (2014). The activity in the analysis of qualitative data was done interactively and lasted continuously until it has been completed and its data reach the point of saturation. Activities in data analysis were data condensation, data display, and drawing conclusion /verification.

\section{Discussion}

On the teaching speaking of narrative text, the teacher initiated without telling the kind of text which the students would learn since she wanted to stimulate the students to analyze the oral text by their own. According to Davies (2007) the most important part is determining the story. The teacher here chose the existing story to tell, she prepared story very well. The teacher gave the example of the story at the beginning of the learning processes. She intended to give a 
model of storytelling video in front of the students. By giving an example of storytelling at the beginning, she tried to encourage the students to express the feeling in speaking activity.

The students were asked to perform storytelling twice, at first they asked to tell the story which the teacher played. They performed in front of the classroom one by one and it took long time to finish. The teacher gave practice before they recorded their voice. In the first performance the teacher gave overall correction to the students' storytelling. After that, they had to make a digital storytelling as the assignment. Based on the theory stated in chapter two, storytelling does not stop in the classroom, there must be extensive activity or homework. Thus, the students were asked to practice storytelling outside the classroom by recording their voice (Davies).

The teacher also monitored the progress of the students' assignment from preparing the text, making the storyboard, until finishing the digital product. It was very important to know the progress of each student to ease student's difficulty during the learning process. Since the ability to speak well in a target language was an important goal for many learners, here an important role of the teachers was to find ways to provide support (especially for reserved students) so that learners have the motivation to practice, and the confident to face interactive opportunities, free of anxiety which might otherwise inhibit their endeavor (Griffiths).

\section{Advantages and Disadvantages of Digital Storytelling in Teaching Spoken Narrative Text}

In the teaching and learning process, digital story telling had advantages and disadvantages to either teacher or students. According to study results, teachers use digital storytelling as a learning tool in their classroom for some main purposes.

\begin{tabular}{|l|l|l|l|}
\hline No & Advantages & Disadvantages & Findings \\
\hline 1. & $\begin{array}{l}\text { Motivating and engaging } \\
\text { (Ohler) }\end{array}$ & & $\begin{array}{l}\text { students are engaged in the } \\
\text { process showing pride in } \\
\text { their work and committing } \\
\text { time to develop their stories }\end{array}$ \\
\hline 2. & $\begin{array}{l}\text { Give more opportunities to } \\
\text { speak. } \\
\text { (Kajder; Robin) }\end{array}$ & $\begin{array}{l}\text { Many students indicated that } \\
\text { creating stories provided } \\
\text { them with more opportunities } \\
\text { to communicate meaningfully } \\
\text { with their friends and fellow } \\
\text { students }\end{array}$ \\
\hline
\end{tabular}




\begin{tabular}{|l|l|l|l|}
\hline 3. & $\begin{array}{l}\text { Self-confidence (Hull \& Katz; } \\
\text { Ware) }\end{array}$ & $\begin{array}{l}\text { The students did not feel shy } \\
\text { practicing speaking because } \\
\text { they did not tell in front of the } \\
\text { audience. They only faced } \\
\text { their laptop. it increased their } \\
\text { self-confidence. }\end{array}$ \\
\hline 4. & $\begin{array}{l}\text { Creativity } \\
\text { (Hull \& Katz) }\end{array}$ & $\begin{array}{l}\text { Students narrated the movie } \\
\text { according to the pictures of } \\
\text { the theme They were } \\
\text { encouraged to add } \\
\text { background music while they } \\
\text { were speaking. }\end{array}$ \\
\hline 5. & Challenges with the tool. & $\begin{array}{l}\text { The teacher noted that some } \\
\text { students who did not know } \\
\text { how to download images and } \\
\text { order the video clips had } \\
\text { difficulty getting started with } \\
\text { Corel Videostudio. }\end{array}$ \\
\hline
\end{tabular}

Table 1. Advantages and disadvatages of digital storytelling

\section{Traditional Storytelling vs. Digital Storytelling}

In the teaching and learning process, digital storytelling has significant role to decrease students' anxiety in speaking. This study proved that when the students were asked to perform telling story in front of the classroom, many of them were shy and could not perform well. They felt afraid of making mistakes if doing traditional storytelling; because they practice speaking in front of the teacher and friends. Somehow, using digital storytelling increases the students' confidence to speak since they don't need to face other people.

\begin{tabular}{|l|l|l|}
\hline Traditional Storytelling & Digital Storytelling & Finding \\
\hline $\begin{array}{l}\text { Discourage } \\
\text { (Robin). }\end{array}$ & $\begin{array}{l}\text { Encourage } \\
\text { (Robin). }\end{array}$ & $\begin{array}{l}\text { The students tended to speak by } \\
\text { using digital storytelling rather } \\
\text { than traditional storytelling. }\end{array}$ \\
\hline $\begin{array}{l}\text { Solve problems within the } \\
\text { structure of the story. }\end{array}$ & $\begin{array}{l}\text { Broader than the structure } \\
\text { of the story. } \\
\text { (Schiro) }\end{array}$ & $\begin{array}{l}\text { The students only focused on how } \\
\text { to narrate the story with abstract } \\
\text { description when involved in } \\
\text { traditional storytelling (the first } \\
\text { performance) }\end{array}$ \\
\hline
\end{tabular}

Table 2. Traditional Storytelling vs Digital Storytelling

\section{The Students' Responses to the Use of Digital Storytelling}

According to the findings, it can be seen that students had positive opinions on using the digital storytelling to improve their English speaking skills. Most of them enjoyed using the 
digital storytelling. From the semi-structured interview, they agreed that the digital storytelling was a very useful tool for education. Many students also said that they were able to improve their pronunciation when they recorded their voices as part of the digital storytelling project. As Kuforiji \& Williams (2011) stated in their research, students found that digital storytelling was an enjoyable activity in the classroom. It is important to consider whether the students will enjoy studying English when designing appropriate lessons and activities.

Moreover, students like the digital storytelling because it is easy to use for practicing English speaking. Afrilyasanti \& Basthomi (2011) mentioned that digital storytelling can be easily implemented in the classroom. Many students liked the easy steps of creating their own digital storytelling by using Corel VideoStudios, and then presented the story. As Reinders (2011) mentioned, digital storytelling is a compelling activity for the language classroom which is easy to use for speaking practice. It can be a good way to motivate students to use the language both inside and outside the classroom.

Furthermore, Ariffin (2010) discussed the potentials of digital storytelling including experience sharing. So digital storytelling is a usable technology especially for the study of English. Teachers should encourage their students to design their own digital storytelling for sharing their stories with their friends as part of the learning activities in the classroom.

Also, independent learning was promoted when students studied from the digital storytelling. They felt independent in learning English while they were using the software. As Campbell (1977) and Sanprasert (2005) stated, independence in learning encourages learners to gain more knowledge, to make more progress in learning with interesting content, and a variety activities. Students can choose the activities and practice speaking by themselves from the digital storytelling. So, self-learning encourages students to learn to speak more effectively.

However, to design the digital storytelling, teachers should consider some possible problems in inserting storytelling files to the application which may take quite a long time. It is a problem which is related to the application and the quality of the notebook used by the students. Moreover, students need more colorful pictures and graphics on the digital storytelling. Lessons that incorporate images and sounds allow all students, especially those with learning difficulties, to understand concepts better even before reading the text of a lesson 
(Piotrowski \& Reason). Therefore, integrating pictures and graphics into the digital storytelling can motivate students to learn better. More pictures and better graphics need the advanced technology. It is better to use a good notebook/ computer which has the advanced processor in order to make the video quicker.

\section{Students' Digital Storytelling Works}

The students' score was taken from the students' speaking task which had been done in the end of the learning process. The task was in the form of digital storytelling video telling their own story orally. The assessment was based on three aspects which became the teacher's focus during teaching and learning process. They are the students' understanding about the generic structure of narrative text in the implementation of digital storytelling, the students' pronunciation in the implementation of digital storytelling, and the students' vocabulary in the implementation of digital storytelling.

Actually the students had two opportunities to perform the storytelling, the first was at the first and the second meeting in the classroom. At this performance, the teacher did not take the score because it was used to train the students' pronunciation and expression before making the digital storytelling. So, the teacher wanted to make sure that her students had practiced their story. The score was taken after the third meeting outside of the classroom in form of digital storytelling video. This extensive classroom activity was controlled by the teacher. It could be done in the school or outside the school.

Based on the scoring instrument of speaking task, the ability of the students was varied. Some students were able to perform storytelling with almost no mistake in content, understand the generic structure appropriately, no mistake in accuracy and pronunciation, and use a variety of vocabulary. And some other students had good ability in telling story with few mistakes in content and generic structures. They spoke with few mistakes in constructing correct sentence; also they had clear pronunciation but made some errors in word choices. In addition there were some students who were able to tell the story with many mistakes in pronunciation. The pronunciation is unclear, sometimes difficult to understand, they also use limited vocabulary. 
This is not surprising that most of the students got very good score because they had been doing the exercise before they made the video, moreover the students did the storytelling in form of video recording which meant they did the storytelling freely outside of the classroom with less obstacle. It meant that the storytelling of the students were good which covered the content, pronunciation and vocabulary.

However, manual storytelling does not give more exercise to the student to practice speaking. In the classroom, they only had opportunities to practice speaking twice. They need more time to practice. The result of the students's speaking ability will not increase significantly because they had lack of time to practice. The equal oportunities is considered important in learning speaking skill (Ur; Brown). The tendency of some learners to dominate can be decreased through the application of digital storytelling.

The process of creating the digital storytelling proved that this media provided a good atmosphere where the students could participate in the teaching and learning process actively from the first stage untul the last stage (Banaszewski). They did the assignment either inside or outside the classroom. This class assignment provides the teacher with an opportunity to observe the extent of each student's computer literacy (Brenner). The teacher and the students discussed well about the narrative text and the digital storytelling.

The students practiced speaking by recording their voice many times to get the best audio of the story. If the students keep practicing in communication continually, their skill in communication in the foreign language will be developed (River).

\section{Conclusion}

After analyzing and discussing the result of this research, the researcher concludes that teaching speaking of narrative text through digital storytelling consisted of two phase. The first phase is conducted in the classroom. The students had to prepare and practice their narrative draft before making the video. Then, they made the digital storytelling video outside the classrom. The video might be made anywhere because the students had known the steps of making the video well. At last, the students had to submit their works to teacher's flashdrive to evaluate. 
From the discussion on the students' response stated in previous chapter, it can be seen that the students were interested with the digital storytelling they have made. The activity of creating the video is very challenging and gives more chance for them to practice speaking. They tend to like the story which is familiar in their daily life. They also enjoyed discussing the digital storytelling either in the classroom or outside the classroom with the role of the teacher who supports them. They also expected that the digital storytelling would be able to enhance their ability in speaking.

The result of students' speaking assessment test showed that the ability of the students was varied. Not all students reached the speaking criteria from O'Malley and Pierce's scoring rubric. Some students were able to perform storytelling with almost no mistake in content, understand the generic structure appropriately, no mistake in accuracy and pronunciation, and use a variety of vocabulary. And some other students had good ability in telling story with few mistakes in content and generic structures. They spoke with few mistakes in constructing correct sentence; also they had clear pronunciation but made some errors in word choices. In addition there were some students who were able to tell the story with many mistakes in pronunciation. The pronunciation is unclear, sometimes difficult to understand, they also use limited vocabulary.

\section{Bibliography}

Afrilyasanti, Rida and Basthomi, Yazid. "A Case Study on the Teaching of Speaking to Indonesian EFL Students." Language in India no.11, 2011, pp. 81-91.

Ariffin, A.M. “ Digital Storytelling: An Easy-to-create Usable Information Conveyor.” Journal of Information Technology Review, vol .1, no. 1, 2010, pp. 30-36.

Ary, Donald, Jacobs, Lucy Cheser, and Sorensen, Christine K. Introduction to Research in Education, Eighth Edition. Canada: Wadsworth, 2010.

Brenner, Kathy. “ Digital Stories: A 21st-Century Communication Tool for the English Language Classroom." English Teaching Forum,no. 1, 2014, pp. 22-29.

Banaszewski, Thomas, M. Digital Storytelling: Supporting Digital Literacy in Grades. Georgia Institute of Technology. Unpublished Paper, 2005, pp. 4-12 
Brown, H, Douglas. Language Assessment: Principles and Classroom Practices. New York: Longman, 2004.

. Principles of Language Learning and Teaching. New York. Pearson Education,

Inc, 2007.

. Teaching by Principles: an Interactive Approach to Language Pedagogy. New

York: Pearson Education, 2001.

Bull, G., and Kajder, S. "Digital Storytelling in the Language Arts." Classroom. Learning and Leading with Technology, vol. 32, no. 4, 2004, p.4.

Campbel, C.P. Vocational raining: Maximizing Individualization with Instructional Packages, 1977. [On-line].Available:

http://eric.ed.gov/ERICWebPortal/search/detailmini.jsp?_nfpb=true\&ERICExt

Davies, Alison. Storytelling in the Classroom: Enhancing Oral Traditional Skills for Teachers and Pupils. London: Paul Chapman Publishing, 2007.

Firza, Faradina Dia. “ The implementation of digital storytelling in writing recount text to second graders of junior high." Unpublished. Thesis. Surabaya: Unesa, 2013.

Griffiths, Carol. Lessons from Good Language Learners. New York: Cambridge University Press, 2008.

Harmer, Jeremy. The Practice of English Language Teaching. London: Longman, 1998.

Hull, G. A. \& Katz, M. L. "Crafting an agentive self: Case studies of digital storytelling." Research in the Teaching of English, vol. 41, no. 1, 2006, pp. 43-81.

Kajder, S. B. “ Enter here: Personal narrative and digital storytelling.” English Journal, vol. 93, no. 3, 2004, pp. 64-68.

Kathleen, Bailey M, and Nunan. Practical English Language Teaching: Speaking. New York: McGraw Hill Companies, 2005.

Kuforiji, P.O. \& William, B.F. Using digital storytelling in the development of reflective educators, 2011. [On-line]. Available: http://http://www.nssa.us/tech_journal/volume_1-3/vol1_article_6.htm

McMillan, J. H. Educational research: Fundamentals for the consumer. Boston: Pearson, 1992. 
Milles, Matthew B., Huberman, A. Michael, and Saldana, Johhny. Qualitative Data Analysis: A Methods Sourcebook. Thousand Oaks: SAGE Publication, Ltd., 2014.

Ohler, Jason B. Telling your story: A handbook for putting the story into digital (and traditional) storytelling. Juneau, AK: Brinton Books, 2007.

. Digital Storytelling in the Classroom: New Media Pathways to Literacy, Learning, and Creativity. London: Sage Publication, Ltd., 2007.

. Digital storytelling in the classroom: New media pathways to literacy, learning, and creativity. Thousand Oaks, CA: Corwin Press, 2008.

O'Malley, J. Michael and Pierce, Lorraine Valdez. Authenic Assessment for English Language Learners. New York: Addison-Wesley Publishing Company, 2005.

Piotrowski, J. \& Reason, R. “ The National Literacy Strategy and Dyslexia: A Comparison of Teaching Methods and Materials." Support for Learning. Vol. 15, no. 2, 2000, pp. 51-58.

Porter, Bernajean. "Digital Storytelling: Across the Curriculum." Summer Storytelling Camp, 2009, pp. 7-9.

Reinders, H. “Digital Storytelling in the Language Classroom.” ELTWO Journal, vol. 3, 2011.

River, W. M. Speaking in Many Tounges: Essay in Foreign Language Teaching. New York: Cambridge University Press, 1983.

Robin, B. R. "Digital storytelling: A powerful technology tool for the 21st century classroom." Theory Into Practice, vol. 47, 2008, pp. 220-228.

Sadik, A. "Digital storytelling: a meaningful technology-integrated approach for engaging student learning." Education Technology Research Development, vol. 56, 2008, pp. 487506.

Sanprasert, N. Learners' attitudes towards the use of English through poetry program in comparison with the same lesson in a paper-based material, 2005. [On-line]. Available: http://www.ecls.ncl.ac.uk/publish/volume2/Navaporn/ navaporn.pdf

Schiro, M. Oral storytelling and teaching mathematics. Thousand Oaks, CA: SAGE Publications, 2004.

Skouge, J. R., \& Rao, K. “Digital storytelling in teacher education: Creating transformations through narrative." Educational Perspectives, vol. 42, no. 1, 2009, pp. 54-60. 
Suleiman, Wal Alfida. "Digital Storytelling to Sharpen Language Skills." Paper presented at the Proceedings of the 3rd International Conference of Teaching and Learning (ICTL), Malaysia, 2011.

Ur, Penny.. A Course in Language Teaching. Cambridge: Cambridge University Press, 1996.

Ware, P. D. "From sharing time to showtime! Valuing diverse venues for storytelling in technology-rich classrooms." Language Arts, vol. 84, no. 1, 2006, pp. 45-54.

Muhammad Mujtaba Mitra Zuana 